\title{
Supporting Informtaion:
}

\section{Tissue Contaminants and Associated Transcriptional Response in Trout} Liver from Remote High Elevation Lakes of Western Washington, USA

\author{
Patrick W. Moran*,\#, Neelakanteswar Aluru ${ }^{\dagger}$, Robert W. Black* , and \\ Mathilakath M. Vijayan ${ }^{\dagger}$
}

*U.S. Geological Survey Washington Water Science Center, Tacoma, Washington, USA, and ${ }^{\dagger}$ Department of Biology, University of Waterloo, Waterloo, Ontario, Canada

${ }^{\#}$ Corresponding Author: Patrick Moran, U.S. Geological Survey, Washington Water
Science Center, Tacoma, Washington, U.S.A. 253-552-1581, pwmoran@usgs.gov

Robert W. Black, U.S. Geological Survey, Tacoma, WA USA 98402

rwblack@usgs.gov

Neelakanteswar Aluru, Biology Department, Univ. of Waterloo, Ontario, Canada N2L 3G1

naluru@sciborg.uwaterloo.ca

Mathilakath M. Vijayan, Biology Department, Univ. of Waterloo, Ontario, Canada N2L 3G1

mvijayan@sciborg.uwaterloo.ca 
Supporting Information for “Tissue Contaminants and Associated Transcriptional

Response in Trout Liver from Remote High Elevation Lakes of Western Washington, USA" Moran, Aluru et al 3/2007

\section{Methods (continued) \\ Sediment Characterization}

Subsamples of sediments were taken for measurement of acid volatile sulfides (AVS), following the method of (1), while organic carbon content, measured as loss on ignition, pore-water sulfides, and percent solids were characterized from each composite sediment sample by the USGS Columbia Environmental Research Center (Columbia, MO). Subsamples for sediment grain size were collected and evaluated across five size categories by the USGS Iowa Sediment Laboratory (Iowa City, Iowa). AVS, organic carbon content, and grain size analysis data are summarized below in Table 1 of SI.

\section{Microarray Sample Processing:}

cDNA synthesis and labeling: Fifty micrograms of intact total RNA (either lake sample or reference RNA) were indirectly labeled following the Institute for Genomic Research TIGR protocol (http://www.tigr.org/tdb/microarray/protocolsTIGR.shtml) with the red fluorescent dye ester cyanine 5 (Cy5) and green fluorescent dye ester cyanine 3 (Cy3) (Amersham Biosciences, Piscataway, NJ). Dye swapping was carried out by switching the reference RNA dye labeling between slides. In brief, cDNA was synthesized by incorporating aminoallyl dUTP (AA-dUTP) at $42^{\circ} \mathrm{C}$ for $3 \mathrm{~h}$. RNA was hydrolyzed with $10 \mu \mathrm{L}$ of $1 \mathrm{M} \mathrm{NaOH}$ and $10 \mu \mathrm{L}$ of $0.5 \mathrm{M}$ EDTA for 15 min at $70^{\circ} \mathrm{C}$ and 
neutralized by adding $10 \mu \mathrm{L}$ of $1 \mathrm{M} \mathrm{HCl}$. To remove unincorporated AA-dUTP and free amines, the reactions were purified with Qiagen columns using phosphate wash buffer and phosphate elution buffer. The purified sample was dried in a speed vac and AAcDNA was resuspended in $0.1 \mathrm{M}$ sodium bicarbonate buffer, and coupling to the Cyanine dye ester was performed for $90 \mathrm{~min}$ in the dark at room temperature. The removal of uncoupled dye was performed using the Qiagen PCR Purification Kit.

Hybridization and post-processing: Before hybridization the $\mathrm{Cy} 3$ and $\mathrm{Cy} 5$ labeled samples were combined and dried in a speed vac. To the dried sample $26 \mu \mathrm{L}$ of hybridization buffer and $2 \mu \mathrm{L}$ each of calf thymus DNA $(10 \mathrm{mg} / \mathrm{ml})$ and yeast tRNA (10 $\mathrm{mg} / \mathrm{ml}$ ) were added. The samples were denatured for $2 \mathrm{~min}$ at $95^{\circ} \mathrm{C}$, snap cooled on ice for $1 \mathrm{~min}$, and centrifuged for $1 \mathrm{~min}$ at maximum speed. The solution was pipetted onto the microarray slide placed in a hybridization chamber and the cover slip was placed carefully. Hybridization was done overnight in a water bath at $37^{\circ} \mathrm{C}$.

After hybridization, the microarray slide was taken out of the chamber, and the cover slip was removed by immersion in a low stringency wash buffer (1X SSC, $0.2 \%$ SDS). The slide was then washed for $10 \mathrm{~min}$ in low stringency wash buffer, $5 \mathrm{~min}$ in high stringency wash buffer ( $0.1 \mathrm{x}$ SSC, $0.2 \%$ SDS, and MilliQ water), and twice for $2.5 \mathrm{~min}$ in $0.1 \mathrm{X} \mathrm{SSC}$. Low stringency washing was done at $48^{\circ} \mathrm{C}$ whereas the remaining washing steps were carried out at room temperature with shaking. Finally, the slides were quickly dipped in MilliQ water and centrifuged at 1,000 $\mathrm{g}$ for $2 \mathrm{~min}$ in a $50 \mathrm{ml}$ Falcon tube at room temperature for drying.

Image analysis: Image analysis was carried out using Versarray chipreader software Version 3.1 (BioRad, Hercules, CA). For each microarray slide, two images were 
produced by illuminating the array at $650 \mathrm{~nm}$ (excitation of Cy5) and $549 \mathrm{~nm}(\mathrm{Cy} 3)$.

Fluorescent images of hybridized arrays were acquired immediately at $10 \mu \mathrm{m}$ resolution using Versarray chipreader software. The same laser power (90\%) and photomultiplier tube (PMT; Cy3 PMT 75-80, Cy5 PMT 70-75) settings were used for all slides in the study.

Spot finding and quantification was carried out with ImaGene 3.0 microarray image analysis software (BioDiscovery; Los Angeles, CA). Briefly, a grid was created taking into account the number of spots, the printing pattern, and the size of the spots. Spot finding was performed using a semiautomatic method in which each spot is checked for proper alignment within the grid manually. Finally, spot quantification was performed to obtain the expression level of each gene on the array.

Data analysis: The data analysis was done using microarray data analysis system (MIDAS) following methods by Saeed et al (2). Poor or negative control spots were flagged as unreliable and were excluded from the analysis. For each spot, signal/noise (SN) threshold was calculated using the following formula: $[I(A$ or $B)+B k g(A$ or B $)] /$ $B k g(A$ or $B)$, where I(A) and I (B) denotes background corrected signal intensity for channel $\mathrm{A}$ and $\mathrm{B} ; \mathrm{Bkg}(\mathrm{A})$ and $\mathrm{Bkg}(\mathrm{B})$ denotes background intensity for channel $\mathrm{A}$ and $\mathrm{B}$ respectively. The SN ratios for each channel was compared to the set threshold value of 2.0 and any spots which are less than or equal to 2.0 were marked as bad and excluded from downstream analysis. The data were then LOWESS (Locally Weighted Regression and Smoothing Scatterplots) (3) normalized using block or sub-grid mode where the LOWESS factor for each spot was computed by assuming that only those spots within the same sub-grid contribute to the bias. Smoothing parameter, a percentage number used by 
MIDAS to compute LOWESS factor for each spot was set at 33\%. Either Cy3 or Cy5 was selected as the reference based on the labeling of the reference pool in each slide. Log ratios of the normalized gene intensity for each sample (fold change relative to the reference pool) were then calculated. The raw dataset has been deposited into the Gene Expression Omnibus (http://www.ncbi.nlm.nih.gov/geo, series GSE6886).

Quantitative real-time PCR (qPCR): To validate the reliability of the microarray results, a few genes that were significantly different between lakes were randomly picked for gene quantification by means of quantitative real-time PCR (qPCR). cDNA synthesis: The first strand cDNA was synthesized from $1 \mu \mathrm{g}$ of total RNA using first Strand cDNA synthesis kit (MBI Fermentas, Burlington, ON). Briefly, total RNA was heat denatured $\left(70^{\circ} \mathrm{C}\right)$ and cooled on ice. The sample was used in a $20 \mu \mathrm{l}$ reverse transcriptase reaction using $0.5 \mu \mathrm{g}$ oligo $\mathrm{d}(\mathrm{T})$ primers and $1 \mathrm{mM}$ each dNTP, $20 \mathrm{U}$ ribonuclease inhibitors, and $40 \mathrm{U}$ M-MuLV reverse transcriptase. The reaction was incubated at $37^{\circ} \mathrm{C}$ for $1 \mathrm{~h}$ and stopped by heating at $70{ }^{\circ} \mathrm{C}$ for $10 \mathrm{~min}$.

Relative standard curve: Relative standard curves for the genes were constructed using serial dilutions of plasmid vector stock with inserted target sequences according to established protocols (4). The primers were designed using rainbow trout sequences; the details of the gene accession numbers, primer sequences, melting temperatures, and the size of the amplified product are given in Table 5 of SI. Platinum ${ }^{\circledR}$ Quantitative PCR SuperMix-UDG (Invitrogen, CA) used was $2 \mathrm{X}$ concentrated and every $25 \mu \mathrm{l}$ reaction had 1.5 U Platinum Taq DNA polymerase, $20 \mathrm{mM}$ Tris- $\mathrm{HCl}(\mathrm{pH} 8.4), 50 \mathrm{mM} \mathrm{KCl}, 3 \mathrm{mM}$ MgCl2, $200 \mu \mathrm{M}$ dGTP, $200 \mu \mathrm{M}$ dATP, $200 \mu \mathrm{M}$ dCTP, $400 \mu \mathrm{M}$ dUTP, and 1 U UDG; the reaction also contained $0.2 \mu \mathrm{M}$ forward and reverse primers, fluoroscein calibration 
dye (1:2000; BioRad) and SYBR Green I nucleic acid gel stain (1:100,000; Roche, Quebec). Master mixes, to reduce pipetting errors, were prepared at every stage for triplicate reactions $(3 \times 25 \mu l)$ for each standard. Specific PCR plates were used according to the manufacturer's instructions (BioRad).

Quantification: One $\mu 1$ of cDNA sample was used as a template for every $25 \mu 1$ reaction of target genes, and half a $\mu \mathrm{l}$ of cDNA was used as a template for $\beta$-actin. Each sample was set-up in triplicates for the $\mathrm{qPCR}$ (iCycler, BioRad). The reaction components were exactly the same as the previous section, and for every single test sample, a qPCR for both the target and the housekeeping gene ( $\beta$-actin) was performed. The following PCR cycle was used for gene amplification: $95^{\circ} \mathrm{C}-3 \mathrm{~min} ; 40$ cycles: denaturing $95^{\circ} \mathrm{C}-30 \mathrm{~s}$, annealing (Table 5) - $30 \mathrm{~s}$, extend $72{ }^{\circ} \mathrm{C}-30 \mathrm{~s}$, followed by $4{ }^{\circ} \mathrm{C}$ hold at the end of the PCR reaction. The transcript abundance for each gene was calculated from the threshold cycles $\left(\mathrm{C}_{\mathrm{T}}\right)$ using their respective standard curves followed by normalization with $\beta$ actin. 


\section{Literature Cited}

(1) Allen, H. E.; Gongmin, F.; Deng, B. Analysis of Acid-Volatile Sulfide (AVS) and Simultaneously Extracted Metals (SEM) for the Estimation of Potential Toxicity in Aquatic Sediments. Environ. Toxicol. and Chem. 1993, 12, 1441-1453.

(2) Saeed AI, Sharov V, White J, Li J, Liang W, Bhagabati N, Braisted J, Klapa M, Currier T, Thiagarajan M, Sturn A, Snuffin M, Rezantsev A, Popov D, Ryltsov A, Kostukovich E, Borisovsky I, Liu Z, Vinsavich A, Trush V, Quackenbush J. TM4: a free, open-source system for microarray data management and analysis.

Biotechniques. 2003, 34, 374-378.

(3) Yang, Y. H.; Dudoit, S.; Luu, P.; Lin, D. M.; Peng, V.; Ngai, J.; Speed, T. P. Normalization for cDNA microarray data: a robust composite method addressing single and multiple slide systematic variation. Nucleic Acids Res. 2002, 30, e15.

(4) Sathiyaa R.; Vijayan, M. M. Autoregulation of glucocorticoid receptor by cortisol in rainbow trout hepatocytes. Am. J Physiol. Cell. Physiol. 2003, 284(6), C1508-1515. 


\begin{tabular}{|l|c|c|c|c|c|c|c|c|c|c|}
\hline \multicolumn{1}{|c|}{ Site } & $\begin{array}{c}\text { STHg } \\
\text { Conc } \\
\text { (ng/g } \\
\text { dry) }\end{array}$ & $\begin{array}{c}\text { SMHg } \\
\text { Conc } \\
\text { (ng/g } \\
\text { dry) }\end{array}$ & $\begin{array}{c}\text { \% } \\
<250 \text { um }\end{array}$ & $\begin{array}{c}\text { \% } \\
<62 \text { um }\end{array}$ & $\begin{array}{c}\text { SMHg } \\
\text { Conc } \\
\text { (ng/g } \\
\text { dry) }\end{array}$ & $\begin{array}{c}\text { \% } \\
\text { Lol }\end{array}$ & $\begin{array}{c}\text { pore- } \\
\text { water } \\
\text { sulfides }\end{array}$ & $\begin{array}{c}\text { Dry } \\
\text { Weight } \\
\mathbf{1 0 0 \%}\end{array}$ & $\begin{array}{c}\text { THg/AVS } \\
\text { Ratio }\end{array}$ & $\begin{array}{c}\text { MHg/ AVS } \\
\text { Ratio }\end{array}$ \\
\hline Deadwood & 37.52 & 0.3 & 24 & 60 & 0.3 & 9 & nd & 26.8 & 1.88 & 0.01 \\
\hline Green L, MORA & 30.39 & 1.38 & nc & nc & 1.38 & 34.5 & nd & 33.3 & 2.53 & 0.11 \\
\hline Green L, NOCA & 58.03 & 0.34 & 63 & 20 & 0.34 & 21.0 & nd & 26.3 & 1.16 & 0.01 \\
\hline Skymo & 30.11 & 0.29 & 34 & 35 & 0.29 & 13.7 & nd & 27.6 & 1.25 & 0.01 \\
\hline Wilcox & 28.43 & 0.44 & 19 & 43 & 0.44 & 12.0 & nd & 36.4 & 1.58 & 0.02 \\
\hline
\end{tabular}

Table 1. Sediment pore water sulfides, Total mercury (THg), Methyl mercury (MHg), percent dry weight, grain sizes, and mercury to Acid Volatile Sulfides (AVS) ratios in lake sediments from five high alpine lakes in Washington. (MORA- Mt. Rainier National Park, NOCA- North Cascades National Park). 


\begin{tabular}{|c|c|c|c|c|c|}
\hline \multirow[b]{2}{*}{ Analyte } & \multirow[b]{2}{*}{ CAS Number } & \multicolumn{2}{|c|}{ Tissue } & \multicolumn{2}{|c|}{ Sediment } \\
\hline & & $\begin{array}{c}\text { MRL }(\mu \mathrm{g} / \mathrm{kg} \\
\text { ww) }\end{array}$ & $\begin{array}{l}\text { Frequency of } \\
\text { detection \% } \\
(n=19)\end{array}$ & $\begin{array}{c}\text { MRL }(\mu \mathrm{g} / \mathrm{kg} \\
\mathrm{dw})\end{array}$ & $\begin{array}{l}\text { Frequency of } \\
\text { detection \% } \\
\quad(n=5)\end{array}$ \\
\hline alpha-HCH & $319-84-6$ & 5 & 0 & 1 & 0 \\
\hline beta-HCH & $319-85-7$ & 5 & 0 & 1 & 0 \\
\hline delta-HCH & $319-86-8$ & 5 & 0 & N/A & N/A \\
\hline Aldrin & $309-00-2$ & 5 & 0 & 1 & 0 \\
\hline Pentachloroanisole & $1825-21-4$ & 5 & 0 & 1 & 0 \\
\hline Hexachlorobenzene & $118-74-1$ & 5 & 0 & 1 & 0 \\
\hline Chloroneb & $2675-77-6$ & N/A & N/A & 5 & 0 \\
\hline cis-Chlordane & $5103-71-9$ & 5 & 0 & 1 & 0 \\
\hline cis-Nonachlor & 5103-73-1 & 5 & 0 & 1 & 0 \\
\hline cis-Permethrin & $54774-45-7$ & N/A & N/A & 5 & 0 \\
\hline Dacthal & 1861-32-1 & 5 & 0 & 5 & 0 \\
\hline Dieldrin & $60-57-1$ & 5 & 0 & 1 & 0 \\
\hline alpha-Endosulfan & $959-98-8$ & N/A & N/A & 1 & 0 \\
\hline Endrin & $72-20-8$ & 5 & 0 & 2 & 0 \\
\hline Heptachlor & $76-44-8$ & 5 & 0 & 1 & 0 \\
\hline Heptachlor epoxide & $1024-57-3$ & 5 & 0 & 1 & 0 \\
\hline Isodrin & $465-73-6$ & N/A & N/A & 1 & 0 \\
\hline Lindane & $58-89-9$ & 5 & 0 & 1 & 0 \\
\hline o,p'-Methoxychlor & $30667-99-3$ & 5 & 0 & 5 & 0 \\
\hline p,p'-Methoxychlor & $72-43-5$ & 5 & 0 & 5 & 0 \\
\hline Methyl Mercury & $22967-92-6$ & N/A\# & N/A\# & $0.01^{\$}$ & $100^{\mathrm{D}}$ \\
\hline Mercury, total & $7439-97-6$ & 1 & $100^{A}$ & $7.4^{\$ B}$ & $100^{\mathrm{E}}$ \\
\hline Mirex & $2385-85-5$ & 5 & 0 & 1 & 0 \\
\hline o,p'-DDD & $53-19-0$ & 5 & 0 & 1 & 0 \\
\hline o,p'-DDE & $3424-82-6$ & 5 & 0 & 1 & 0 \\
\hline o,p'-DDT & $789-02-6$ & 5 & 0 & 2 & 0 \\
\hline Oxychlordane & $27304-13-8$ & 5 & 0 & 1 & 0 \\
\hline p,p'-DDD & $72-54-8$ & 5 & 0 & 1 & 0 \\
\hline$p, p^{\prime}-D D E$ & $72-55-9$ & 5 & $83^{\ddagger C}$ & 1 & 0 \\
\hline p,p'-DDT & $50-29-3$ & 5 & 0 & 2 & 0 \\
\hline Total PCBs & $1336-36-3$ & 50 & $22^{\mathrm{B}}$ & 50 & 0 \\
\hline Toxaphene & $8001-35-2$ & 200 & 0 & 200 & 0 \\
\hline trans-Chlordane & $5103-74-2$ & 5 & 0 & 1 & 0 \\
\hline trans-Nonachlor & $39765-80-5$ & 5 & 0 & 1 & 0 \\
\hline trans-Permethrin & 51877-74-8 & N/A & $\mathrm{N} / \mathrm{A}$ & 5 & 0 \\
\hline
\end{tabular}

*Estimated using average wet weight of $78 \%$. ${ }^{\ddagger}$ Detections were estimates at or below the RL.

${ }^{\$}$ Reporting Limit average of several Daily Detection Limits reported by lab.

\#Methyl mercury not analyzed for in tissue; but generally accounts for $>90 \%$ of total mercury in fish tissue

${ }^{A}$ Concentrations range (11-262), 56.2 SD. ${ }^{\mathrm{B}}$ Range 17-20, 1.8 SD. ${ }^{\mathrm{C}}$ Range (1.3-24), 7.5 SD. ${ }^{\mathrm{D}}$ Range (0.08-0.46), 0.18 SD. ${ }^{\mathrm{E}}$ Range (10.0-15.2), 2.6 SD.

Table 2. Analyte, Chemical Abstract Series (CAS) Number, Method Reporting Limit (MRL), and Frequency of Detection (\%) of analytes analyzed for in tissue, whole fish*, and sediment. N/A indicates analyte not analyzed in that media. 


\begin{tabular}{|ccccc|}
\hline & Length $(\mathbf{m m})$ & Weight $\mathbf{( g )}$ & Sex & Gross Abnormalities \\
\hline Skymo & 221 & 98 & $\mathrm{M}$ & no \\
& 252 & 148 & $\mathrm{~F}$ & no \\
& 231 & 102 & $\mathrm{~F}$ & no \\
& 243 & 126 & $\mathrm{M}$ & no \\
& 236 & 119 & $\mathrm{M}$ & no \\
\hline Wilcox & 268 & 146 & $\mathrm{M}$ & Some liver cirrhosis \\
& 164 & 130 & $\mathrm{M}$ & no \\
& 250 & 136 & $\mathrm{~F}$ & no \\
& 247 & 136 & $\mathrm{~F}$ & no \\
& 289 & 200 & $\mathrm{~F}$ & no \\
\hline
\end{tabular}

Table 3. Characteristics of cutthroat trout used in Microarray comparison of least (Skymo) and most (Wilcox) contaminated lakes.

\begin{tabular}{|c|c|c|c|c|c|c|c|c|}
\hline \multirow{2}{*}{$\begin{array}{l}\text { Year } \\
\text { Media \& Contaminant }\end{array}$} & \multicolumn{5}{|c|}{ 2-yr Avg. } & \multicolumn{3}{|c|}{2003} \\
\hline & $\mathrm{F} \mathrm{Hg}$ & F PCB & F DDE & F PCB / lipid & F DDE / lipid & S THG & S MHG & s oc \\
\hline MRL & 0.025 & 50 & 5 & 0.0 & 0.01 & 1.78 & 0.01 & nd \\
\hline Deadwood Lake & 48 & nd & 7.2 & nd & 0.51 & 10 & 0.08 & nd \\
\hline Green L. nr Fairfax & 40.5 & nd & 2.8 & nd & $0.13^{*}$ & 10.1 & 0.46 & nd \\
\hline Green L. nr Marblemount & 144 & $20 \mathrm{E}$ & 17 & 0.94 & 0.80 & 15.2 & 0.09 & nd \\
\hline Skymo Lake & 16 & 17E & 17 & 1.5 & 1.5 & 8.3 & 0.08 & nd \\
\hline Wilcox Lake & 54 & $18 \mathrm{E}$ & 22.5 & 0.57 & 0.72 & 10.3 & 0.16 & nd \\
\hline
\end{tabular}

$\mathrm{E}$ denotes estimated value, * Denotes single year value.

Table 4. Average (2002 and 2003) fish tissue concentration of total mercury (F Hg), total PCBs (F PCB), and pp' DDE (F DDE); and 2003 sediment concentration of total mercury (S THg), methyl mercury (S MHG), and total organochlorines (S OC). . Non-detected (nd) compounds not reported here. MRL indicates Method Reporting Limit. All values in $\mu \mathrm{g} / \mathrm{kg}$ wet weight. 
A

Microarray
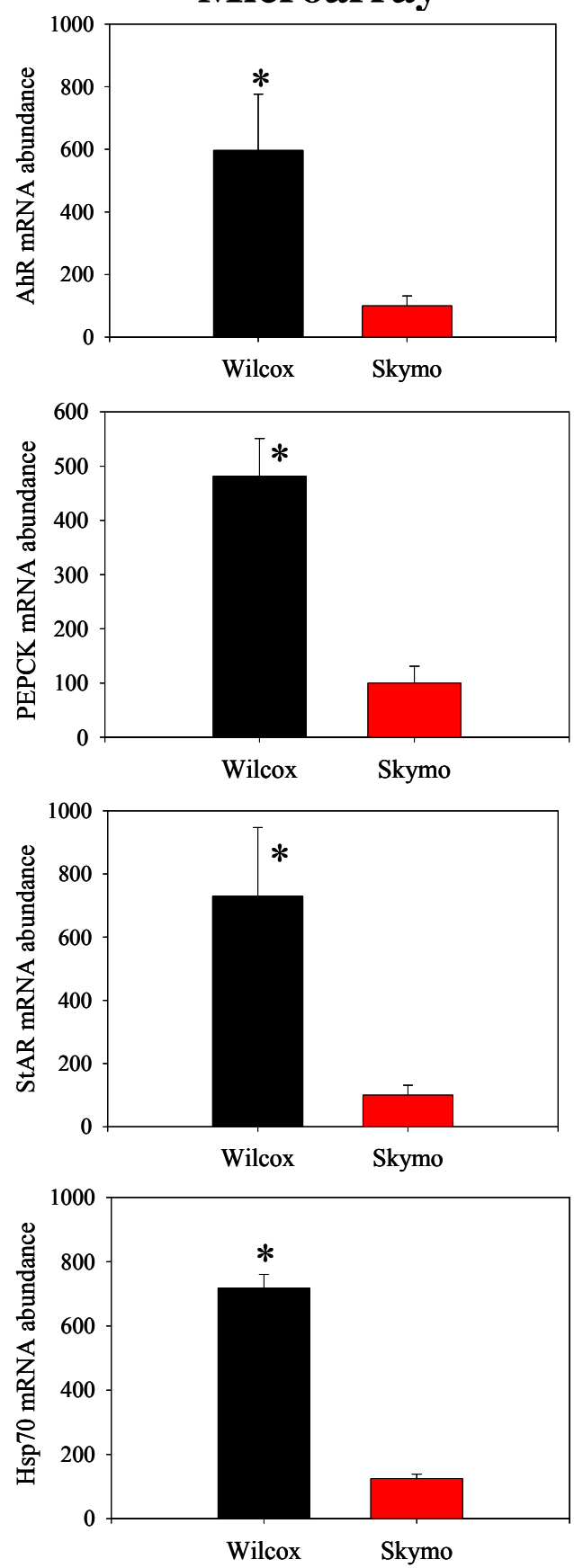

B

Microarray
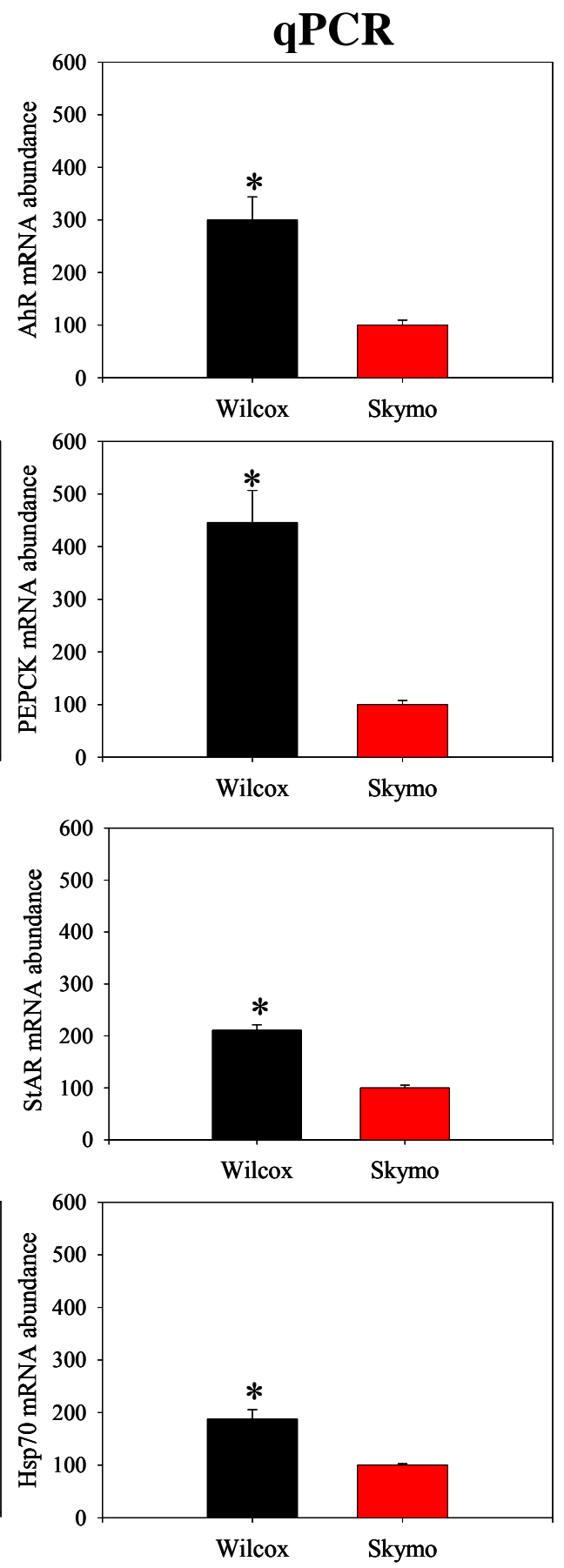

qPCR 

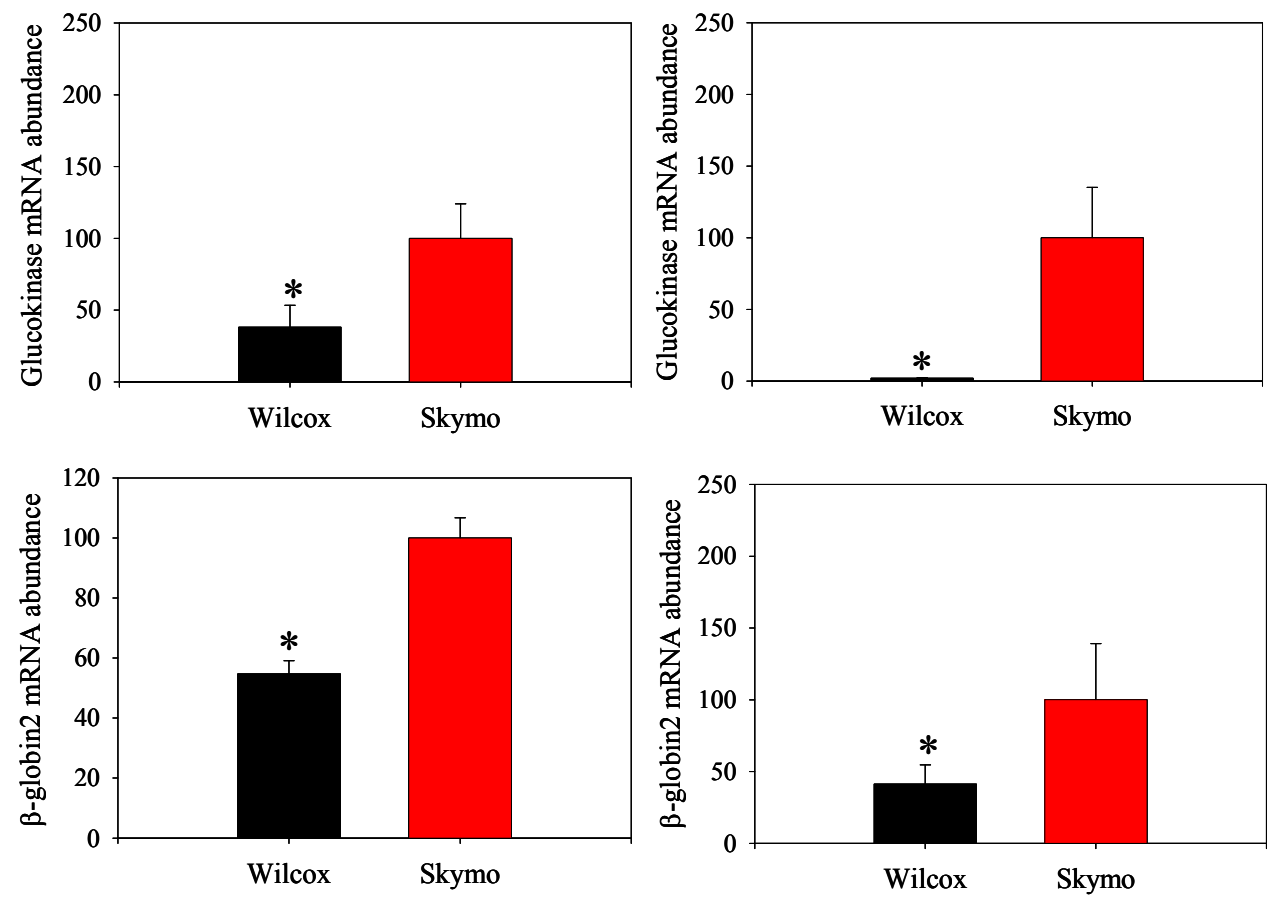

| Figure 1, Comparison of Microarray and quantitative real-time PCR (qPCR) responses of selected upregulated (A) and downregulated genes (B). Wilcox Lake transcript levels are represented as a percent of Skymo Lake levels ( $n=3-5$ independent fish); *significantly different $(\mathrm{p}<0.05$; Student's t-test). 


\begin{tabular}{|c|c|c|c|c|}
\hline Gene & Primers & $\begin{array}{l}\text { Accesion } \\
\text { number }\end{array}$ & Tm & $\begin{array}{c}\text { Product } \\
\text { size }\end{array}$ \\
\hline$\beta$-actin & $\begin{array}{l}\text { Sense 5'-AGAGCTACGAGCTGCCTGAC-3' } \\
\text { Anti-sense 5'-GCAAGACTCCATACCGAGGA-3' }\end{array}$ & AF157514 & $49^{\circ} \mathrm{C}$ & 100 bp \\
\hline StAR protein & $\begin{array}{l}\text { Sense 5'-CGCTGGCATCTCCTACA-3' } \\
\text { Anti-sense 5'-GGGACTTCGTTAGTGTTCG-3' }\end{array}$ & AB047032 & $60^{\circ} \mathrm{C}$ & $500 \mathrm{bp}$ \\
\hline AhR & $\begin{array}{l}\text { sense 5'-CAGCGAGGGGAGCGGTAA-3' } \\
\text { Anti-sense 5'- TGGACCCGGCCAGTGATA-3' }\end{array}$ & $\begin{array}{l}\text { AF065138 } \\
\text { AF065137 }\end{array}$ & $60^{\circ} \mathrm{C}$ & $500 \mathrm{bp}$ \\
\hline PEPCK & $\begin{array}{l}\text { Sense 5'-TGCTGAGTACAAAGGCAAGG-3' } \\
\text { Anti-sense 5'-GAACCAGTTGACGTGGAAGA-3' }\end{array}$ & AF246149 & $49^{\circ} \mathrm{C}$ & 100bp \\
\hline Hsp70 & $\begin{array}{l}\text { Sense 5'-GAAGGTGTCCAATGCAGTCA- 3' } \\
\text { Anti-sense 5'-TGATCCTCAGCCATTCAGC-3' }\end{array}$ & AB062281 & $50^{\circ} \mathrm{C}$ & $100 \mathrm{bp}$ \\
\hline Glucokinase & $\begin{array}{l}\text { Sense 5' -ACAGGGTGGTGGACGAGA -3' } \\
\text { Anti-sense 5' -ACTGCCGAGATAAGTGCCG -3' }\end{array}$ & AF053331 & $56^{\circ} \mathrm{C}$ & $500 \mathrm{bp}$ \\
\hline $\begin{array}{l}\text { P type- } \\
\text { globin2 }\end{array}$ & $\begin{array}{l}\text { Sense 5'-AGCCATCTCCGACATCTT-3' } \\
\text { Anti-sense 5'-TCATTGAGGGGTGAAACA- 3' }\end{array}$ & $\mathrm{AB} 015451.2$ & $51^{\circ} \mathrm{C}$ & 500 bp \\
\hline
\end{tabular}

Table 5. List of oligonucleotide primers used in quantitative real-time PCR confirmation. 